\title{
Paradise Regained: Older adult rock climbers turning space into place in the natural environment.
}

\author{
Mark Hickman, Colin Beard, Alison Inkster
}

Envigogika 10 (3) - Reviewed articles/Recenzované články

Published/Publikováno dne 30. 12. 2015

DOI: $10.14712 / 18023061.502$

\begin{abstract}
.
At the time of writing there are over 10 million people aged over 65 living in the UK, and by 2050 the number is predicted to rise to 19 million. This expansion of the ageing population is mirrored worldwide, and over the past ten years has stimulated a growth in age-related studies. However, the idea of a social gerontology of the outdoors is yet to take root. Yet, with the maturing of those born between the years 1946 and 1964, and increased participation in adventurous activities, we suggest that the time is right for scholarship in this specific direction. Accordingly, the aim of this study was to discover how older adult rock climbers perceived their relationship with the natural environment to have changed over the period of their involvement with rock climbing. The investigation used a purposive sample of rock climbers in the north-west of England $(n=10)$ aged between 65 and 74 years (av=69.6) identifying them as 'young-old' adults. Oral testimony was collected over two phases, the first with interview-questionnaires, and the second with targeted semi-structured interviews. In order to give a clear voice to participants, manual data handling using was used to establish raw data that were then sorted into themes and verified against internal and external checkers. These were then organized around Peace, Wahl, Mollenkopf and Oswald's (2014) concept of an 'environment' considered within three dimensions: the physical/material, including the natural landscape; the psychological, and the meaning attributed to the place, its evolution across the life course, and how it makes people feel about themselves; and the social/cultural characteristics, involving the engagement of people to places, including how the space is used and remembered.
\end{abstract}

\section{Key words}

climbing; environment; social gerontology; stories.

\begin{abstract}
Abstrakt
$\checkmark$ době psaní článku žilo ve Velké Británii více než 10 milionů lidí ve věku nad 65 let, a do roku 2050 se předpokládá, že jejich počet vzroste na 19 milionů. Stárnutí obyvatelstva se projevuje celosvětově, což za posledních deset let podnítilo také vznik mnoha studií na toto téma. Nicméně zkušenosti ze sociální gerontologie $v$ souvislostech $\mathrm{s}$ outdoorovým prostředím dosud nejsou dostatečně zpracovány. Autoři tohoto textu se domnívají, že $v$ době, kdy lidé narození v letech 1946 až 1964 postupně dozrávají a současně se všeobecně zvy-
\end{abstract}


šuje účast v dobrodružných aktivitách, nastal pravý čas ke zkoumání souvisejících jevů. Cílem této studie tak bylo zjistit, jak starší dospělí horolezci vnímali, že se jejich vztah k přírodnímu prostředí ( $v$ době jejich aktivního zájmu o horolezectví) měnil v průběhu let. výzkum se zabýval vybraným vzorkem horolezců ze severozápadu Anglie $(n=10)$ ve věku mezi 65 a 74 let $(\varnothing=69,6)$, které Ize označit jako "mladší-staré" dospělé. Jejich výpovědi byly získány ve více než dvou fázích výzkumu: první z nich bylo dotazníkové šetření, druhá cílené polo-strukturované rozhovory. Aby se respondenti měli přiležitost jasně vyjádřit, záznamy byly zpracovány jednotlivě, čímž byla získána surová data, která byla následně rozdělena podle témat a ověřena interními a externími hodnotiteli. Tyto údaje pak byly uspořádány podle konceptu Wahla, Mollenkopfa a Osvalda (2014) tak, že pojem „životní prostředí" byl uvažován ve třech dimenzích: fyzicko/materiální dimenze, což zahrnuje přírodní krajinu; psychologické dimenze; a podle významu připisovaného místu, s ohledem na vývoj tohoto významu $v$ průběhu života, a z hlediska jeho vlivu na pocity lidí a jejich sebeuvědomění; přičemž byly zohledněny i další sociální / kulturní charakteristiky, jako je zapojení lidí do místních aktivit a způsoby využití prostoru i jeho stopa v paměti.

\section{Klíčová slova}

horolezectví; životní prostředí; sociální gerontologie; př́běhy. 


\section{Introduction}

Baby boomers' is a term that has been used to describe the generation born after World War Two and between the years 1946 and 1964 (Cochran, Rothschadl \& Rudick, 2009). Explanations for this two-decade rise in birth rates are varied and complex, but best understood against a background of soldiers returning from war-zones, married couples looking to have children after putting family life on hold during a period of great uncertainty, an increasingly positive and stable economic climate, and changing social values.

By 2011, those at the leading edge of this 'age-wave' (Dytchwald \& Flower, 1989) had reached 65 , the retirement age in the UK, and at the time of writing there are in excess of ten million people aged $65+$ in the UK with the number predicted to rise to 19 million by 2050; currently, one-sixth of the UK population falls into this age group a figure expected to be one-quarter by 2050 (Rutherford, 2012).

In recent years there has been an increased interest in age-related studies across academic fields such as sociology (Gilleard \& Higgs, 2014), psychology (Johnson, Bengtson, Coleman \& Kirkwood, 2005), demography (McDaniel \& Zimmer, 2013), leisure (Toepoel, 2013), cultural studies (Twigg \& Martin, 2015) and biology (Kuh, Cooper, Richards, Gale, von Zglinicki \& Guralnik, 2012). However, there has been little discussion about a gerontology of the outdoors.

Another major problem is that despite changing contours on the map of ageing, there is no universally recognized age that is considered to be 'old', and Levine (2008) points out that any designation by which people are categorized as 'old' is dependent on the bias of the classifier. Working conditions, access to good nutrition and health care, stress and lifestyle can lead to wide discrepancies between chronological age, calculated by date of birth, and biological age, reflected by the morbidity and the physical state of the human body. According to Levine (2008: 5), therefore, due to local conditions 50 should be considered old in Africa. Most recently, researchers have added to this debate by developing a molecular 'ageing test' that is claimed to accurately determine a person's biological age which might be younger or older than their actual chronological age (Sood, Gallagher, Lunnon, Rullman, Keohane, Crossland, Phillips, Cederholm, Jensen, van Loon, Lannfelt, Kraus, Atherton, Howard, Gustafsson, Hodges and Timmons, 2015).

Thus, Gallie (1964) might argue that 'age' is an essentially contested concept where there is absolute agreement that 'it' does exist but debate over when 'it' actually begins. Such disunity adds a layer of confusion and difficulty to any research project seeking a universally agreed baseline, and the absence of a clear and consensual accord amongst experts in the field ensures that all starting points will be arbitrary and subject to criticism. However, whilst it is not one of the stated aims of this piece of work to resolve terminological disagreements a starting point is necessary. Therefore, an approach was sourced from Brennan (2008) who investigated the relationship between experiential learning and adventure in a group of mature adults and based his categorization of age on three distinct phases: 'young-old' from 65-74; 'old-old' from 75-84; and 'oldest-old' from 85 onwards. Subsequently, participants in this present study were sought from the 65-74 year old age range and can be classified as being 'young-old'.

Historically, concepts of ageing have often characterized later life as a period of illness, decline, dependency and burden (Vertinsky, 1995; Fiennes, 2013), and as recently as 15 years' ago, Pipher's (2000) work still suggested that these conditions were an inevitable concomitant of ageing, that the ageing process itself remained beyond mediation or management, and that the elderly, 
"...walk a road filled with potholes of pain, low energy, poor appetite and inadequate sleep. They lead lives filled with loss of friends and family, of habits and pleasures and autonomy" (30).

However, more recent data shows that our understanding of ageing is being challenged and re-conceptualized. Along with better education, healthcare and enhanced levels of personal responsibility older adults are emerging as fitter, and of crucial importance, aspirational in terms of new ways to spend time. The previously dominant narrative about inevitable decline and morbidity is being rewritten especially through the emerging field of gerontology, a multi-disciplinary consideration of the biological, psychological and social aspects of the ageing process. In particular, social gerontologists look at the complex interplay between demography, economics, social anthropology and sociology to help understand ageing and change (Dannefer \& Phillipson, 2010).

Whilst it is incontrovertible that the elderly are more prone to heart conditions, osteoporosis, slower reactions and a weakening of the immune-system (Taylor \& Johnson, 2008; Stuart-Hamilton, 2011) and a degree of degeneration of the human body and mind is inevitable, an increasing number of sources show that it can be slowed down and the ravages of premature ageing kept in abeyance (Chodzko-Zajko \& ACSM, 2013; Norman, 2010; Spirduso, Poon and Chodzko-Zajko, 2007). In particular, evidence suggests a very positive correlation between physical and cognitive activity and well-being past the age of 65 ( $\mathrm{Ni}$ mrod, 2007; 2011).

However, Perrault's (1983:3) observation that "there is substantial evidence to support the notion that exercise may be an effective way to delay the effects of ageing" needs to be considered in the light of Pelletier's (1984) findings that at the age of 65 those who were optimistic and engaged in meaningful recreational projects were most likely to lead positive and rewarding lives into their seventies and beyond. Furthermore, as McAdams (1993) and Grant and Kluge (2007) show, those who are able to constantly review and reinterpret their lives in positive ways seem most successful in navigating the ageing process.

With little attention having been paid to the gerontology of the outdoors adventure sports should be regarded as a site for serious scholarly enquiry. Rather than physical activity for older adults taking the traditional form of continuous exercise of a repetitive nature, such as running, cycling, swimming, or joining a gym, more recent arguments have endorsed active ageing taking the form of a 'project' as more likely to attract older adults and see greater rates of adherence (Stebbins, 2006; Elkington and Stebbins, 2014). This 'serious leisure' (Cohen-Gewerc and Stebbins, 2013) involves a systematic pursuit of sufficient interest to require the development of specialist skills, knowledge and experience (Cohen-Gewerc, 2013). This paper attempts to show that the environment can and does play a significant role in this respect and evidence is beginning to emerge that sea kayaking, crosscountry skiing, mountaineering, caving and fell-running are other equally valid examples of activities where the natural environment contributes to a sense of health and well being (Hickman \& Doherty, 2015; Hooper \& Hickman, 2015; Inkster, Hickman \& Beard, 2015a; Inkster, Hickman \& Beard, 2015b). Attachment to a given environment and what this can mean to the older adult has been explored in various contexts by other researchers, and we will now briefly consider them.

Peace, Wahl, Mollenkopf and Oswald (2014: 209) clearly show how the concept of an 'environment' can be considered within three dimensions:

- Physical/material: including the natural landscape. 
- Psychological: the meaning attributed to the place, its evolution across the life course, and how it makes people feel about themselves

- Social/cultural: engagement of people to places, including how the space is used and remembered.

However, they also suggest that there is a tendency in the research community to "de-contextualise" (2014: 210) ageing from the environment or space where it takes place. Recent attempts to redress this have focused on the task of creating age-friendly communities within the built environment and creating spaces in which older adults feel safe and can negotiate without problems (Buffel, 2015). But work still needs to be done to understand the relationship between ageing, adventure and the natural environment.

This current research aims to contextualize ageing within a specific space and to do so in an area less frequented by gerontologists. In doing so, it challenges Lawton and Simon's (1968) notions of age and increasing environmental docility and suggests instead that for older rock climbers the natural environment acts as the scaffold for increased engagement, which in turn promotes enhanced physical and cognitive well-being: such ideas have more in common with Carp and Carp (1984) and Maslow's ideas about human needs (1987).

There is also increased scholarship in the concept of pedagogy of place, or how the environment affects the capacity to learn (Somerville et al., 2011). Whilst this tends to focus again primarily on the built environment, Wattchow and Brown (2011) have applied this specifically to outdoor education. Nevertheless, there remains the opportunity for serious consideration as to how older adults connect or re-connect with space and time at the junction between the natural environment and adventure.

It has also been suggested that older adults create habitus or familiar 'place' (Bordieu, 1977; Scheidt \& Schwartz, 2010) from an otherwise neutral 'space'. Being 'in-place' (Rowles \& Watkins, 2003) helps with the creation and maintenance of one's personal history replete with physical, social and autobiographical meanings. Rowles (1983) focuses on how place lends itself to feelings of 'insideness' and its importance to older adults, to the point that place can be "[worn] like a glove" (114). In order to achieve this feeling of comfort, three elements are necessary, social insideness, physical insideness and autobiographical insideness. As McAdams (1993) shows, this is an evolutionary process, changing as the situation determines in order to create a sense of cohesion, meaning and continuity and thus bring about perceptions of stability and value. It is this process, engaged with over time that forms the focus of this work, and it is to the methodology to achieve that that we now turn.

\section{Methodology}

Just like any other phenomenon, age is experienced in different ways. Small and Gillies (2012) consider the range of challenges facing the researcher in the face of an ageing population, stating that active and focused research is critical to generating sound data, understanding the situation and drawing informed conclusions. In turn, this will allow both researchers and applied practitioners to appreciate more fully how the ageing process is perceived and experienced by individuals within specific contexts, and to shape access to the natural environment accordingly.

Thus, although many investigations reduce growing older to anonymous data in an attempt to understand the 'science' of ageing, such a positivist approach, with its reliance on rationality and objectivity would be ill suited to shaping an awareness of how individuals 
perceive and understand the natural environment. Indeed, Barrett and Greenaway (1995) suggested that qualitative approaches were necessary to bring balance to the studies conducted in a scientific manner. It was decided instead, therefore, that the best methodology to adopt for this study would be qualitative, an approach allowing researchers to "interpret phenomena in terms of the meanings that people bring to them" (Denzin \& Lincoln, 2005: 3). Additionally, Crotty (1998: 42) suggests that:

"all knowledge, and therefore, all meaningful reality as such, is contingent upon human practices being constructed in and out of interaction between human beings and their world, and developed within an essentially social context".

Investigation described in this article takes the basic premise that ageing, rock climbing and the natural environment are not fixed phenomena experienced in the same or even similar ways. Instead it adopts the view that there are subjective differences, and that these bring richness and texture to the research. Furthermore, and critically for this work, such differences and standpoints evolve over time. In order to facilitate a more positive discourse on the relationship between the natural environment and healthy ageing three things are necessary. One is to chart the trends of active (and in this case adventurous) involvement in the outdoors by those aged $65+$. The second requires a technical reassessment of the capabilities of older adults in order to understand the cognitive and physical impacts of this involvement. The third is to give voice to the human story and allow older adults to clearly articulate their current experiences. In a few short years, the personal evidence of the first cohort of baby boomers to transition through young-old adulthood (those born between 1946 and 1955) will no longer be available and it is important that present scholars take the time to set these perceptions on record.

As active outdoor practitioners ourselves, we adopted opportunistic or insider research roles (Anderson, 2006) and recognize that this brings both advantages and disadvantages to the research process. In terms of the latter we had to be constantly, and consciously, vigilant to avoid the trap of habituated thinking (Greenleaf, 2002) and interpreting climbers' responses without criticality. However, engaging with a community of practice in which we were accepted as equals must also be accorded its benefits. This made us aware of the subtleties of the socio-political and historical factors affecting climbers' participation and we remained alert to the nuances of behaviour that convert researchers might miss (Lois, 2003). Being participants in the sense-making community thus made it likely that our research would yield insights of potential interest to both participants and a wider audience (Lave \& Wenger, 1991; Weick, 1995; Raelin, 2008).

We established contact with climbers at crags in the north-west of England and extended invitations to take part in the research; the voluntary nature of the investigation was stressed and those expressing an interest asked to initiate further contact. The result was a sample that was both convenience and purposive and expanded using the snowball technique (Flick, 2014). After 16 initial contacts ten eventually took part and with an average age of 68.4 years, this placed them comfortably in the 'young-old' category as defined by Brennan (2008). Eight participants were male, two female, anecdotally reflecting the preponderance of older males (as compared to older females) at the rock faces. Robinson (2008) touches upon the inter-relationship between masculinities and 'extreme' sports and shows how, in the past at least, females were often relegated to the roles of 'belay' or 'shuttle' bunnies for climbers and white water kayakers respectively, which might explain the ratio of responses. More information on active female rock climbers aged between 65 and 74 would help establish a greater clarity on this matter. 
A small sample size had the strength that it allowed for an understanding of social life beyond superficial appearance and helped identify issues worthy of deeper consideration (Crouch, 2006; Lundkvist, Gustafsson, Hjalm \& Hassmén, 2012): generalization was not an aim of this work and its economy is taken into account. In order that participants could be described and recognized as climbers, we used guidelines from the British Mountaineering Council (BMC) that suggested competence at French Grade 4 (F4) would be an appropriate standard to require regular practice.

Two stages were used in the data collection process. Whilst difficult to convene due to the geographical spread of participants, a semi-structured focus group proved useful as a starting point and generated a number of helpful insights that might have been inaccessible without the group setting (Mesquita, Coutinho, De Martin-Silva, Parente, Farca \& Afonso, 2015). This was followed up with targeted semi-structured interviews to tease out more detail (Espirito Santo \& Cordeiro, 2014). Permission to record both stages prior to transcription was sought in order to include the richness of emphasis, inflexion and tonality of the spoken word. Manual Interpretative Phenomenological Analysis (IPA) was used to allow data to inform the flow of the study as opposed to existing data constraining ideas (Larkin, Watts \& Clifton, 2006; Smith, Flowers \& Larkin, 2011). Additionally, internal and external checkers were used to challenge and confirm ideas, one of whom was a clinical psychologist with experience in gerontology. It was through critical consideration with these checkers that the selection of relevant quotations from participants was made. Citations were chosen to capture the essence of how the meanings attached to the natural environment had evolved through the process of ageing.

The thick descriptions afforded by the spoken word were used to create lower and higher order themes for further consideration and helped illuminate the varied human experiences of the natural environment through the perceptions of older rock climbers (Fade, 2004). Human experiences are built on interaction, in this case with the natural environment as well as with fellow climbers, and these emerged as resources that are helping some older adults navigate the challenges of ageing and change.

\section{Discussion}

\section{The Physical and Material Environment}

"For years, probably since when I was a Cub [Scout] I've yearned for physical excitement and adventure. I can take a bit of a back seat now, though, and realize that all through my life that's kept me grounded and externally focused. Whenever work was tough, and there's been some of those times, believe me, climbing, getting out, was always my escape. It was like the jigsaw piece that was missing, except I always knew where it was. Getting out's changed, though. It's not the same now, at nearly seventy, as it was when I was nearly twenty. Where I get out to [has] changed as well. Not in a physical way, the crags are more or less the same now as they've always been, just the way I see them. That's changed." (Male, Ken, Date of Birth: 1948).

The story that Ken told started at an early age with an introduction to the outdoors through Scouting just after he had passed the age of six in 1954. Like many Cub Scout packs and Scout troops of his day, there was something of a military backdrop to training, and Ken remembers one leader who all held in awe due to his being a recent Korean War veteran. "He knew how to live in the outdoors" Ken commented, "how to use the natural environment to best advantage, but to him it was just where we went [...] and, of course, we learned to 
copy him". Not surprisingly, with National Servicemen gravitating towards scouting, much of the language describing the outdoors was also quite militaristic. "It was also just after Everest had been 'conquered'" Ken went on, "[...] everything was described in terms of sieges and assaults, and when we were doing any navigation work, even getting to the crag to climb, it was all about ground: near ground, middle ground, and far ground, just like we were sighting rifles or looking for the enemy, not that there were many of them in rural Lancashire". This disconnection of climbing from the natural environment (Peace et al., 2014) was a feeling experienced also by others:

"At 17, when I was going out climbing, I didn't notice much, and cared less about even more. In fact, I cared about climbing much to the exclusion of everything else, except maybe my exams. The environment? Didn't even notice it let alone care about it. Not in today's sense that it has a character of its own, an identity, even a vulnerability." (Male, Mark, Date of Birth: 1948).

In his last sentence, Mark alludes to the process of change over the years. As a young man he was totally fixated on the climb, something we will return to later, but now, in his late sixties, he has developed a broader awareness that the activity could only occur in the context of a place:

"Looking back I am horrified by my own adolescent sensitivity, or lack of it. I had a mental immaturity and that reflected itself, in part, in my relationship to the natural environment: I say 'to' [because] it wasn't 'with'. It was always there, in the background, changing with the seasons and for the most part I missed it. The only 'season' was the climbing season and my only worry was good or bad weather."

Harold continued the theme of consuming the environment, and of a military approach rather than a partnership:

"I drove too fast to get to the climb to notice much else, least of all the environment. It's a pretty modern thing, anyway, to think of the environment as a place with needs, almost as a character. My walk in [to the climb] was dominated by the focus on the climb. My 'assault' was important, and doing it better than my [climbing] partner. Not the environment." (Male, Harold, Date of Birth: 1944).

Ray offered another perspective:

"[Also] in the Sixties there were significantly fewer people in the natural environment than there are now. There weren't [the numbers of] people there to damage it, but looking back I know we did, not willingly, just through what we did. [The environment] just wasn't on my horizon at all. Caring for the environment wasn't an issue. Vietnam, and later Prague, maybe, but not the environment. It was invisible. Socially, collectively, the environment just wasn't relative. Even less so to an apprenticed toolmaker." (Male, Ray, Date of Birth: 1947).

For many of the participants, the environment had been perceived of as stable and unchanging but invisible, and as Wattchow and Brown (2011) suggest, reconnecting with time and space allows for different, quite revisionist, histories to emerge. More than once participants admitted that the topic invited them to think differently, to revisit their concepts of the environment. For most, if not all, it was difficult to pinpoint when environmental 'space' became imbued with the spirit of 'place', with Jen touching on elements of reinvention (McAdams, 1993):

"You know, we're in a time now where environmental sensitivity is all important, and I wonder if we as climbers just reflect our conformity. [...] we like to think we're all 
counter culture and rebellious and all, more so when we were younger. Now we're all just glad to be still getting out [climbing], maybe that's still the rebel in us all, doing what we're not expected to, or supposed to at our age. But I think, would we really have changed over the years without the environmental lobby, without the environment being in the papers and on the news all the time? Or do we just claim that we're interested because it's socially expected now? I do wonder about that." (Female, Jen, Date of Birth: 1944).

For Teddie, the environment remained a 'space' until his early fifties, only after that did it begin to assume the role of 'place':

"[Until] then only the climbing meant anything to me. I was too busy to notice. Now, I'm into the total wrap-round experience. My last climb was at Troy Quarry, with a mate of mine, [who is aged] 55. Half the morning we spent looking at the water lilies in the pond there. Water lilies. I first climbed there in what, '65 or '66, and probably didn't even see the pond." (Male, Teddie, Date of Birth: 1944).

For Ken, Mark, Harold, Ray, Jen and Teddie, there had been a sense of physical insideness with the natural environment, but one that was not necessarily synonymous with connectedness. That had not emerged until well into mature adulthood. Another participant, Martin, who linked his early experiences of going to climb to his memories of going to the cinema, 'the pictures', on a Saturday morning with his friends, best encapsulated this. "Climbing was like going to a film at the Gaumont" he said, "a big old art deco place, pulled down when I was, oh in my thirties I guess". He went on:

"We used to get so excited, me and my chum, Phil. We'd go and see the cowboy films, and they always used to play the National Anthem. But we went to see the films, we never even noticed the place where we were watching them, it was all just red carpet and big stairs. Climbing was the same. We went to climb, and the environment was just like a big outdoor Gaumont: we might have been in it but we didn't relate to it." (Male, Martin, Date of Birth: 1945).

All agreed that there had eventually been a change in their relationship to and with the natural environment, but that these changes had occurred more through psychological and social mechanisms rather than due to the material of physical landscape, and it is the first of these that we will now consider.

\section{Psychological Change}

Psychological change is central to the way in which older adult climbers' relationships to and with the natural environment have evolved. It is here that we find notions of when that change occurred and, for some, why. Of further interest is the way these changes align with McAdams' (1993) ideas about individuals re-conceptualizing their past in order to make not only their present more manageable and acceptable, but also to make their history more cogent. This is not to suggest any overt manipulation or dissimulation but that the stability associated with being believable starts from within. As both Goffman (1990) and Leary (1996) suggest having a 'personal front' is critical for defining both the individual and the 'character' performance they select to meet the demands of any given social situation. Of course, a complex interplay takes place between an individual's relatively consistent psychological core, their typical responses to given social situations and the role related behaviours they observe, learn and adapt in order to cope with these fluid social situations (Weinberg \& Gould, 2007). In these respects, older adults are constantly encountering situations where they have to navigate the new and evolving terrain of their advancing years. 
Iain had enjoyed a successful career as a vascular surgeon, moving onto academic surgery prior to retiring at the age of sixty; he started rock climbing at the age of fourteen, and still regularly climbed overseas, most recently in the Dolomites. At sixty-nine, he was still tall, sinewy, committed to the mountains and had retrained as a climbing instructor working mainly with youngsters under the age of 14 and "silver haired fellow travellers" as he affectionately termed older adults.

For Iain carving out an identity was the main driver throughout his teenage years, and this was achieved through the activity not the location:

"As a teenager, I definitely wanted more experience to give me credibility as 'a climber' whatever that meant then, and status, I wanted status too. I wanted it all to define who I was, and to show why I was different. And the more of those I got, the more I wanted. And everything was quite straightforward: I got [that] through climbing. Some of my chums got it through cricket, but not their relationship to the field; others through gymnastics, but not through the gym. The activity was king. And my activity was king, with proper adventure, risk and danger all tacked on." (Male, Iain, Date of Birth: 1946).

Like his climbing peers, the environment had simply been a material backdrop for his adventures, and perhaps more than most he was aware of the motivational shifts behind this. He was also clear about the psychological journey he had been on:

"Whether I was trying to do this for myself, or for others, I'm not quite sure. I was aiming for a military scholarship to see me through medical school, so part of it was probably to try to add a bit of machismo to my [Curriculum Vitae], show them I was tough enough."

He also admitted that climbing was probably symptomatic of other pressures in his life:

"Now, I'm happy with who I am, still love climbing, but see the bigger picture. The journey's seen me change, for the better, I think, but for what was, I guess, the majority of my life, it wasn't like that."

What had shaped Iain's experiences of the natural environment once he reached young adulthood was a combination of time, or lack of it, and a constant pressure to be successful in his career: climbing evolved into an antidote to the tensions of juggling work and family life:

"Back then, probably until two or three years before I [retired] my entire physical and mental make-up was geared to spikes of very high intensity. It was course after course, exam after exam, prove myself in theatre, marriage and be a good father, then teaching, research and papers. All of these required high-octane spikes. When I climbed in my thirties and forties, I think part of me was trying to show that I was successful in everything I did. But to do that I had to concentrate on maintaining my [climbing] grade, not where I was climbing. That's the surgical mentality. I climbed in Sikkim and Ladakh, even in Ulan Bator, and I peak bagged - I came home with trophies not images of where I had been. But if the graph was all spikey when I was younger, now there's a steady and constant line. I now take the time to see more, to appreciate the things I didn't 'have the eye to see' then."

Iain's perspective resonated with Lisbeth's. The first in her family to go to university, a degree in economics followed by chartered accountancy status, and then experience across public and private sectors before retiring from educational finance in her mid-fifties. She 
now trains and assesses groups of young people in the Duke of Edinburgh's Award Scheme. "When I'm away with young adults," she observed:

"I still see it. The younger the person, the less they'll see. Teens, well they're all focus on the climb or the walk [in the mountains] because it's all new. Twenties to mid-forties, still focused on the activity in the main but for different reasons. They're squeezing their climbing or walking alongside careers, children and other responsibilities. They have to carve out some precious 'me-time' and they want to use it in a way they feel they've achieved something. It's not really until later that there's any environmental awareness, and that's because they've got more time and less pressure."

For Lisbeth and Iain striving for success and recognition had characterized their young and mature adulthood. When asked, both agreed that this period could be seen as one where the natural landscape acted as a mirror or surrogate for the professional environment: this interrelationship of space(s) created a singular habitus where accomplishment could be played out and communicated to others. "Looking back", Lisbeth said thoughtfully:

"I was time-poor back then. I was too busy ticking off routes to see Nature. Consciously or unconsciously, I don't know, I was in a sport where achievement was reflected in the grade you were climbing at, the climbs at that grade that you'd done, and your 'projects' as they call them now, you know, your plans."

She described how from her twenties to her late forties her career had involved a lot of moves to both gain varied experience and achieve promotion. There had been many work spaces, within which she had focused on the tasks associated with being successful. There had been no psychological or emotional attachment to these spaces, they were simply where she practiced her skills: so too with the natural environment.

The latter began to evolve from a space to a place after a very amicable divorce from her husband. "[He] wasn't a climber" she explained, "[We'd] had some common interests, mainly the [three] kids, but we'd also kept some space for ourselves; [his] was cycling, mine was climbing". She went on:

"[He'd] been a competitive cyclist in his teens, stayed on the club scene and was as serious about it as I was with my climbing. Every weekend we tried to do stuff for the kids. Funnily, never climbing really, that was my escape; even though now I work with youngsters. Then alternate Sundays [my husband and] I did [our] thing. All of a sudden, with the kids flown the nest, the youngest just about to go off to uni[versity] we realized our interests were just different. However, when I went climbing, I no longer needed to get home quite so quickly. I also got a small house with an equally small garden and decided that I need to have somewhere nice to sit outside. That was probably the real changing point. As I was learning to be a gardener, it struck me how much time I'd spent in Nature but had been oblivious to it."

It appears that for Lisbeth divorce had been the catalyst that broke with her perspective of the natural environment. At this critical time, the natural environment provided continuity and stability at a time of fundamental change, and she was able to make connections between her previous and new lives. Place began informing de-contextualized space, and fulfilling a range of new psychological needs (Carp \& Carp, 1984; Maslow, 1987). "Now", Lisbeth explains, "when I'm out with youngsters I try to point out everything, all the things that were always there for me but weren't because I was too busy being busy, if that makes any sense, [and] though most are still focused on the activity, they are environmentally aware and that makes them more receptive". 
From his mid-fifties onwards, the natural environment had also provided somewhere safe for Clive (Buffel, 2015). Born in 1950, and just within Brennan's (2008) category of being a 'young-old' adult, Clive had first joined the Royal Marines and then retrained as a teacher of physical education (PE). A physically active lifestyle, including developing his interests in climbing and hill walking into a successful adventure sports course at the college where he had worked, had led to tendon problems: "And there's no retirement home for old PE teachers", he lamented, "only the knacker's yard". His role had gradually been taken over by younger, more mobile teachers, and at the age of 58 he had taken early retirement: "I jumped before I was pushed", he observed wryly. However, unable to continue at satisfactory levels in his other sports, he had found his concept of identity under threat. The vacuum left by no longer practicing judo or gymnastics was slowly filled by climbing and mountain walking, allowing him to maintain his concept of fitness, something fundamental to his well-being. "I worried at first" he explained, "that my fitness was going to go, and all those skills that I'd built up over the years were going to be lost". He found himself first joining a local mountaineering club, and then becoming a walk leader for a commercial adventure activity provider, something he now uses to supplement his pensioner's income. It was the natural environment that allowed him the opportunity to cope. "Of course, I have lost those skills", he said nostalgically:

"At first I felt a great sense of loss, but I started doing more outdoor stuff, just to fill my time. I made more effort to do easy multi-pitches where I could keep up my endurance; I started doing longer routes; more overnighters. Not having to be back for training meant I had more time to be out. Gradually, I began to realize that I could climb and mountaineer at levels that were equally physical, but less rough and tumble, there was none of the impact or the rotational forces. Once I was warmed up, everything was steady, nice and steady. Basically, I changed my perspective on adventure, and now think that older adults should be encouraged to take up climbing and hill walking. It's all self-paced, there's no competition, it can be as social, or not, as you like, and now I'm into the geology and geography as never before."

For Clive, the natural environment assumed a greater importance as a context for learning and coping: about the physicality that was so central to his life, and about how others could be encouraged to participate. "Most of my outdoor pursuits till nearly sixty had been about going in an upwardly direction", he confessed:

"[...] topping out on a route or bagging a peak. I'd hardly ever bothered with lower level activities. Then, with time on my hands I started looking more about the glaciology and so on, and thought 'how come I'd not bothered with this before?' I started getting my climbing 'oppos' [partners] more involved, and eventually someone suggested becoming a walk leader. Now I spend as much of my outdoor time contouring with groups at low level as I do climbing."

Much like Iain and Lisbeth, a seminal change in Clive's life had led to the natural environment being re-discovered and elements of 'physical insideness' (Rowles, 1983) that had existed to a smaller degree in his past assumed greater importance. For all, their experiences had also been tempered by a social and cultural engagement with the natural environment, something that enhanced 'autobiographical insideness' and contributed to meaning and stability across the life course (McAdams, 1993).

\section{The Social and Cultural Environment}

Kim and Moen (2001) clearly show how developmental and social contexts help shape an individual's experiences of retirement. Of course, in today's shifting economic climate, there is no universally recognized age at which withdrawal from the labour force occurs, and 
irrespective of an arbitrary point in time some people need to remain at work to maintain an income, as did Clive, and to a certain extent, Lisbeth, whilst others, such as Iain, use work to define the later stages in their life course (Principi, Jensen \& Lamura, 2014). For all three, the natural environment not only proved the context where this took place, but also involved a rediscovery of meaning, the transformation of space into place.

Martin's employment as a salesman of building supplies for housing developments all over the UK, and particularly in the south midlands and Home Counties, meant that once he had left his native Cumberland he had considered himself unsettled. He had lived in many houses but home had always been a place in the northwest of England. His experience of climbing venues had been more diverse than most, located wherever he was living at the time, and also overseas. Still choosing to work part-time to fund several months' overseas 'retirement climbing' every year in Mallorca, Greece and most recently Morocco, for Martin, the natural environment had been the backdrop for stability and social connectivity with likeminded individuals. "I was constantly on the move," he explained:

"My wife, bless her, looked after James and Louise, but I probably spent two, sometimes three nights away every week. Of course, I missed them, [...] but it was my job, it's how I paid the mortgage. I could cover easily a thousand miles a week, staying wherever. But, rather than just early nights in hotels, I quickly pitched up wherever the local climbers were. It meant I carried my gear in the car, got out to some fantastic great, and got familiar with some of them. I got to know the usual faces, too, people who shared a passion for climbing. Otherwise, I'd have just watched the telly on my own."

Martin etched out his habitus from disparate climbing venues, overcoming the potential loneliness of separation from loved ones, and making familiar places of crags and climbing areas. For him, the natural environment became his habitus, especially as he and his wife moved house on average once every six to eight years. "We got to know the route to schools, the shops and the kids' clubs, more so Steph[anie] than me", he went on:

"And that was all. But even now, I can go back to any of those crags and I feel settled straight away, in familiar and comfortable places. Then I get my guidebook out, and look when I last did the climb, I always marked it with a date and who I climbed it with. And I wonder, where are they now? What are they up to? And I think of the laughs we had, and the escapes, there were some of those too."

In potentially very anonymous work surroundings, the natural environment provided Martin with a degree of familiarity, and to an extent some stability.

Others too saw their relationship with the natural environment as a motif for ageing and their journey through the life course. Returning to Ken, when younger he had been so focused on the climb that once he had brought his partner to the top, their over riding compulsion was to get to the bottom of another route and start all over again. "Now", he suggested:

"The golden moments are at the top, and being able to look out at the world and know that out there in all that technology and rush there's an unchangingness [sic] and a peace. It's like I've got all the pieces to my jigsaw, and then some. Best of all are the summer evenings, when you can be topping out at ten or half-ten, and there's a silence. Then I've got a bridge that allows me to walk all along the bits of my life, the places and the people, the rough times and the smooth. They're all there, and I don't want to rush them. Only it's taken me the best part of a lifetime to realize it. And I guess that's one thing about growing old, you can read about it, 
keep yourself in good [condition], eat right, but only when you're there can you understand it. I suppose it's the same for every generation, it probably was for my dad. What does Clapton say, 'through my father's eyes' or something?"

\section{Conclusion}

Much is made of using the 'outdoors' as a public health resource for health intervention strategies (Ashton, 2014; Varney \& Whyte, 2015). One of the issues to emerge from these findings is that the natural environment has significant potential to be employed in a positive way to maintain the health and well-being of older adults. For the participants involved in this study, the natural environment has provided at once both stability and change, expressed in each instance in very positive ways. What has been startlingly clear is that contrary to Lawton and Simon's (1968) notions that along with age there comes increased 'environmental docility', and Peace, Wahl, Mollenkopf and Oswald's (2014) ideas that age de-contextualizes people from their environment, growing older for this cohort has afforded greater involvement with the natural environment and a broader and deeper engagement with its meanings.

Therefore, if our appreciation of the relationship between ageing and the natural environment is to be moved forward more research is necessary into the ways in which older adults transform neutral space into familiar place. Additionally, the specific role played by adventure sports in this process requires consideration.

As indicated by Kim \& Moen (2001), developmental and social contexts help shape an individual's experience of retirement, and life after work should be considered within life course and ecological contexts: thus studying the retirement process as it develops, and how the complex interplay between rock climbing and the natural environment continues to unfold is another important next step in this research. All of the participants in this investigation could be categorized as 'young-old' (Brennan, 2008), and it would be interesting to follow their path to uncover the meanings they are yet to make and attribute to the natural environment as they transition from this stage to 'old-old' adulthood between the ages of 75 and 84 .

More broadly, research is also needed to position ageing in the natural environment as a site of serious academic study and to establish the credibility of gerontology studies focusing on the role of adventure.

However, perhaps the final word should go to Jen:

"I realize that the [natural environment has] been so good to me, and sometimes I think maybe I'm trying to banish the fear of the unknown, you know, about getting really old, by drowning it out in the familiar sights and sounds of the past, in my glory days."

\section{References}

- Anderson, L. (2006). Analytic Autoethnography. Journal of Contemporary Ethnography, 35(4), 373-395. Retrieved from http://jce.sagepub.com/cgi/doi/10.1177/0891241605280449 http://dx.doi.org/10.1177/0891241605280449 
- Ashton, J. (2014). The developing role for the outdoor sector driving public health and wellbeing: How does the Outdoor Sector work with health and wellbeing services and funding? Keynote speech given at the Institute for Outdoor Learning National Conference. Loughborough, UK. 17th October.. Loughborough, UK: Loughborough, UK. 17th October.

- Barrett, J., \& Greenaway, R. (1995). Why adventure? The role and value of outdoor adventure in young people?s personal and social development. Coventry: Foundation for Outdoor Adventure.

- Bordieu, P. (1977). Outline of a Theory of Practice. Cambridge: Cambridge University Press. Retrieved from http://ebooks.cambridge.org/ref/id/CBO9780511812507 http://dx.doi.org/10.1017/CBO9780511812507

- Brennan, D. (2008). Older Adults in Adventure Education: Making Meaning of Older Adults' Inner Experience of Experiential Education. Saarbrücken: VDM Verlag Dr. Muller.

- Buffel, T. (Ed.), (2015). Researching Age-Friendly Communities: Stories from older people as co-investigators. Manchester: The University of Manchester Library.

- Carp, F. M., \& Carp, A. (1984) A complimentary/congruence model of well-being or mental health for the community elderly. In I. Altman \& M. P. Lawton (Eds.), Human Behaviour and Environment (pp. 279-336). New York: Plenum Press.

- Chodzko-Zajko, W., \& Acsm, (2013). The American College of Sports Medicine's Exercise for Older Adults. Baltimore, MD.: Lippincott, Williams and Wilkins.

- Cochran, L. J., Rothschadel, A. M., \& Rudick, J. L. (2009). Leisure Programming for Baby Boomers. Champaign, Il.: Human Kinetics.

- Cohen-Gewerc, E., \& Stebbins, R. A. . Serious leisure and individuality. Montreal: McGill-Queen's University Press.

- Crotty, M. (1998). The foundations of social research: Meaning and perspective in the research process. London: Sage.

- Crouch, M., \& McKenzie, H. (2006). The logic of small samples in interview-based qualitative research. Social Science Information, 45(4), 483-499. Retrieved from http://ssi.sagepub.com/cgi/doi/10.1177/0539018406069584 http://dx.doi.org/10.1177/0539018406069584

- Cutchin, M. P. (2013) The Complex Process of becoming At-Home in Assisted Living. In G. D. Rowles \& M. Bernard (Eds.), Environmental Gerontology: Making Meaningful Places in Old Age (pp. 105-124). New York: Springer.

- Dannefer, D., \& Phillipson, C. (2010) Preface. In D. Dannefer \& C. Phillipson (Eds.), The SAGE Handbook of Social Gerontology (pp. 21-24). Thousand Oaks, Calif: Sage.

- Denzin, N. K., \& Lincoln, Y.S. (Eds.), (2005). The SAGE Handbook of Qualitative Research. Thousand Oaks, CA: Sage.

- Dytchwald, K., \& Flower, J. (1989). Agewave. New York: Putnam. 
- Gallie, W. B. (1956). Essentially Contested Concepts. Proceedings of the Aristotelian Society, 56, 167-198.

- Goffman, E. (1990). The Presentation of Self in Everyday Life. New York: Penguin Putnam.

- Elkington, S., \& Stebbins, R. A. (2014). The Serious Leisure Perspective: An Introduction. London: Routledge.

- Espirito Santo, J.N., , \& Cordeiro, B. C. (2014). Permanent education about the risks of biological natural disasters in sports: a descriptive study. Online Brazilian Journal of Nursing, 13(1), 439-441. Retrieved from http://www.objnursing.uff.br/index.php/nursing/article/view/5043

- Fade, S. (2004). Using interpretative phenomenological analysis for public health nutrition and dietetic research: a practical guide. Proc. Nutr. Soc, 63(04), 647-653. Retrieved from http://www.journals.cambridge.org/abstract S0029665104000862 pmid:15831138 http://dx.doi.org/10.1079/PNS2004398

- Fiennes, R. (2013). Cold: Extreme Adventures at the Lowest Temperature Extremes on Earth. London: Simon and Schuster.

- Flick, U. (2014). An Introduction to Qualitative Research. London: Sage.

- Gilleard, C., \& Higgs, P. (2014). Ageing, Corporeality and Embodiment. London: Anthem.

- Grant, B. C., \& Kluge, M. A. (2012) Leisure and Physical Well Being. In H. J. Gibson \& J. F. Singleton (Eds.), Leisure and Ageing: Theory and Practice. Champaign, Il: Human Kinetics.

- Greenleaf, R.K. (2002). Servant Leadership: A Journey into the Nature of Legitimate Power and Greatness. New York. Paulist Press.

- Hickman, M., \& Doherty, P. (2015). A life on the rocks: a methodology for understanding the older adult's experiences of rock climbing. Journal of Qualitative Research in Sports Studies, 9(1), 63-81.

- Hooper, H., \& Hickman, M. (2015). Notes from the underground: Using caving to understand physical activity participation in under represented groups. Paper Presented at the International Adventure Conference. Sheffield Hallam University. 9th - 11th September.. : Paper Presented at the International Adventure Conference. Sheffield Hallam University. 9th ? 11th September.

- Inkster, A., Hickman, M., , \& Beard, C. (2015a). Sea kayaking and ageing: Expanding the agenda for research into the physically active older adult. Paper Presented at the International Adventure Conference. Sheffield Hallam University. 9th - 11th September. .

- Inkster, A., Hickman, M., \& Beard, C. (2015b). Sustaining adventure as we age: Exploring stories as a means to understand the ageing process in older adult sea kayakers from the Scottish Highlands and Islands. Paper Presented at the International Sea Kayaking Educators Conference. Monash University and Outward Bound Hong Kong. Hong Kong. 30th November - 4th December.. . 
- Johnson, M. L., Bengtson, V. L., Coleman, P. G., \& Kirkwood, T. B. L. (2005). The Cambridge Handbook of Age and Ageing. Cambridge: Cambridge University Press. Retrieved from http://dx.doi.org/10.1017/CBO9780511610714

- Kim, J. E., \& Moen, P. (2001). Is retirement good or bad for subjective well-being? Retirement as a life course transition in time and in ecological context. Current $\mathrm{Di}$ rections in Psychological Science, 10(3), 83-86. http://dx.doi.org/10.1111/1467$\underline{8721.00121}$

- Kuh, D., Cooper, R., Richards, M., Gale, C., Zglinicki, T. von, , \& Guralnik, J. (2012). A life course approach to healthy ageing: The HALCyon programme. Public Health, 126(3), 193-195. Retrieved from http://linkinghub.elsevier.com/retrieve/pii/S0033350612000418 http://dx.doi.org/10.1016/j.puhe.2012.01.025

- Larkin, M., Watts, S. \& Clifton, E. (2006). Giving voice and making sense in Interpretative Phenomenological Analysis. Qualitative Research in Psychology. 3 (2), 102-120.

- Lave, J. \& Wenger, E. (1991). Situated Learning: Legitimate Peripheral Participation. Cambridge. Cambridge University Press.

- Lawton, M. P., \& Simon, B. (1968). The Ecology of Social Relationships in Housing for the Elderly. The Gerontologist, 8(2), 108-115. Retrieved from http://gerontologist.oxfordjournals.org/cgi/doi/10.1093/geront/8.2.108 http://dx.doi.org/10.1093/geront/8.2.108

- Leary, M. R. (1996). Self-Presentation: Impression Management and Interpersonal Behaviour. Boulder, CO: Westview.

- Levine, R. (2008). Ageing with Attitude: Growing Older with Dignity and Vitality. Westport, CT: Prager.

- Lois, J. (2003). Heroic Efforts: The Emotional Culture of Search and Rescue Volunteers. New York. New York University Press.

- Lundkvist, E., Gustafsson, H., Hjälm, S., \& Hassmén, P. (2012). An interpretative phenomenological analysis of burnout and recovery in elite soccer coaches. Qualitative Research in Sport, Exercise and Health, 4(3), 400-419. Retrieved from http://www.tandfonline.com/doi/abs/10.1080/2159676X.2012.693526 http://dx.doi.org/10.1080/2159676X.2012.693526

- Maslow, A. H. (1987). Motivation and Personality. New York: Longman.

- McAdams, D. P. (1993). The Stories We Live By: Personal Myths and the Making of the Self. New York: Guildford Press.

- McDaniel, S. A., \& Zimmer, Z. (2013). Global Ageing in the Twenty First Century. Walnut Creek, CA: Surrey. Ashgate.

- Mesquita, I., Coutinho, P., De, L., Martin-Silva, Parente, B., Faria, M., \& Afonso, J. (2015). The Value of Indirect Teaching Strategies in Enhancing Student-Coaches' Learning Engagement.. J Sports Sci Med, 14(3), 657-668. Retrieved from http://europepmc.org/abstract/MED/26336354 pmid:26336354 
- Nimrod, G. (2007). Retirees' Leisure: Activities, Benefits, and their Contribution to Life Satisfaction. Leisure Studies, 26(1), 65-80. Retrieved from http://www.tandfonline.com/doi/abs/10.1080/02614360500333937 http://dx.doi.org/10.1080/02614360500333937

- Nimrod, G. (2011) The impact of leisure activity and innovation on the well being of the very old. In Poon, L.W. and Cohen-Mansfield, J. (Ed.), Understanding the well being in the oldest-old (pp. 240-257). New York: Cambridge University Press.

- Norman, K. A. (2010). Exercise and Wellbeing for Older Adults. Champaign, Il.: Human Kinetics.

- OECD, (2012). Thematic Follow-Up Review of Policies to Improve Labour Market Prospects for Older Workers - United Kingdom.: Retrieved from http://www.oecd.org/els/older\%20Workers\%20UK-MOD.pdf

- Peace, S., Wahl, H., Mollenkopf, H., \& Oswald, F. (2014) Environment and ageing. In Bond, J., Peace, S., Dittmann-Kohli, F. \& G. Westerhof (Eds.), Ageing in Society (pp. 209-234). London: Sage.

- Pelletier, K. (1984) Longevity: Fulfilling our biological potential. In J. Opatz (Ed.), Wellness Promotion Strategies (pp. 46-61). Dubuque, IA: Kendall Hunt.

- Perrault, R. (1983). Opening Remarks. Proceedings of the National Conference on Fitness in the Third Age. Ottawa. November 8-10. 3.. Ottawa: Proceedings of the National Conference on Fitness in the Third Age. Ottawa. November 8-10. 3.

- Pipher, M. (2000). Another Country: Navigating the Emotional Terrain of Our Elders. New York: Riverhead Books.

- Principi, A., Jensen, P. H., Lamura, G., \& (Eds), (2014). Active Ageing: Voluntary Work by Older People in Europe. : Policy Press.

- Raelin, J. (2008). Work-based Learning: Bridging Knowledge and Action in the Workplace. San Fransisco, CA. Jossey-Bass.

- Robinson, V. (2008). Everyday Masculinities and Extreme Sport: Male Identity and Rock Climbing. Oxford. Berg.

- Rowles, G. D. (1983) Geographical dimensions of social support in rural Appalachia. In G. D. Rowles \& R. J. Ohta (Eds.), Aging and Milieu: Environmental Perspectives on Growing Old (pp. 111-130). New York: Academic Press.

- Rowles, G. D., \& Watkins, J. F. (2003) History, habit, heart and hearth: On making spaces into places. In Schaie, K.W., Wahl, H.W., Mollenkopf, H. \& F. Oswald (Eds.), Aging Independently: Living arrangements and mobility (pp. 77-96). New York: Springer.

- Rutherford, T. (2012). Population ageing: Statistics - Commons Library Standard Note.: Retrieved from http://www.parliament.uk/briefing-papers/SNO3228/population-ageing-statistics

- Scheidt, R. J., \& Schwartz, B. (2010) Environmental Gerontology: A Sample of Issues and Applications. In J. C. Cavanaugh \& C. K. Cavanaugh (Eds.), Aging in America (pp. 156-176). Santa Barbara, CA: Praeger. 
- Small, B., \& Gillies, J. (2012) Studying Leisure in the Context of Aging. In H. J. Gibson \& J. F. Singleton (Eds.), Leisure and Aging: Theory and Practice. Champaign, Il.: Human Kinetics.

- Smith, J.A., Flowers, P. \& Larkin, M. (2011). Interpretative Phenomenological AnaIysis: Theory, Method and Research. Thousand Oaks, CA. Sage.

- Sood, S., Gallagher, I. J., Lunnon, K., Rullman, E., Keohane, A., Crossland, H., . . . Timmons, J. A. . A novel multi-tissue RNA diagnostic of healthy ageing relates to cognitive health status. Genome Biol, 16(1), Retrieved from http://genomebiology.com/2015/16/1/185 http://dx.doi.org/10.1186/s13059-015-0750-x

- Somerville, M., Davies, B., Power, K., Gannon, S., \& Carteret, d. (Phoenix), (2011). Place Pedagogy Change. Rotterdam: SensePublishers. Retrieved from http://link.springer.com/10.1007/978-94-6091-615-1 http://dx.doi.org/10.1007/978-94-6091-615-1

- Spirduso, W., Poon, L., \& Chodzko-Zajko, W. (2007). Exercise and its Mediating effects on Cognition (Ageing, Exercise and Cognition). Champaign, Il.: Human Kinetics.

- Stebbins, R. A. (2005). Challenging Mountain Nature: Risk, Motive and Lifestyle in Three Hobbyist Sports. Calgary: Detselig.

- Stebbins, R. A. (2006). Serious Leisure: A Perspective for Our Time. New Jersey: Transaction. Retrieved from http://link.springer.com/10.1007/s12115-001-1023-8 http://dx.doi.org/10.1007/s12115-001-1023-8

- Stuart-Hamilton, I. (2011). An Introduction to Gerontology. Cambridge: Cambridge University Press. Retrieved from http://ebooks.cambridge.org/ref/id/CBO9780511973697 http://dx.doi.org/10.1017/CBO9780511973697

- Taylor, A., \& Johnson, M. (2008). Physiology of Exercise and Healthy Ageing. Champaign, Il.: Human Kinetics.

- Toepoel, V. (2013). Ageing, Leisure, and Social Connectedness: How could Leisure Help Reduce Social Isolation of Older People. Soc Indic Res, 113(1), 355-372. Retrieved from http://link.springer.com/10.1007/s11205-012-0097-6 pmid:23874058 http://dx.doi.org/10.1007/s11205-012-0097-6

- Twigg, J., \& Martin, W. (2015). Routledge Handbook of Cultural Gerontology. London: Routledge.

- Varney, J., \& Whyte, G. (2015). . Sheffield, UK: Physical Activity and the Outdoors Market. Key note speech given at the Outdoor Industries Association European Summit. Sheffield, UK. 14th October..

- Vertinsky, P. (1995). Stereotypes of ageing women and exercise: A historical perspective. Journal of Ageing and Physical Activity, 3(3), 223-237.

- Wattchow, B., \& Brown, M. (2011). A Pedagogy of Place: Outdoor education for a changing world. Victoria: Monash University Publishing.

- Weick, K.E. (1995). Sensemaking in Organizations. Thousand Oaks, CA. Sage. 
- Weinberg, R.S. \& Gould, D. (2007). Foundations of Sport and Exercise Psychology. Champaign, Il. Human Kinetics. 